\title{
Toward the Development of a Global Financial Safety Net or
}

\section{a Segmentation of the Global Financial Architecture?*}

\author{
Ulrich Volz** \\ SOAS, University of London and German Development Institute
}

\begin{abstract}
April 2016
This article examines the prospects for the development of a comprehensive global financial safety net (GFSN). It discusses the optimal layout of the GFSN, comprising the International Monetary Fund, regional financing arrangements (RFAs), as well as bilateral or multilateral central bank swap arrangements, and the relationship between these. It then briefly reviews and appraises the current structure and functioning of these different layers of the GFSN and discusses the need and scope for strengthening cooperation between RFAs and the IMF. It argues that the GFSN is still very patchy and there is little reason to expect significant progress in better collaboration between RFAs and the IMF as long as the latter's governance structure is not significantly revamped. Indeed, risks are that the GFSN will become even more fragmented with the further development of the European Stability Mechanism and the emergence of the BRICS Contingent Reserve Arrangement. To prevent a further fragmentation of the GFSN, substantial governance reform of the IMF is urgently needed.
\end{abstract}

Keywords: Global financial safety net; IMF; regional financing arrangements; international financial cooperation; international monetary and financial stability.

* I am grateful for helpful comments and suggestions received from two anonymous referees and participants of the $2015 \mathrm{KDI}$ Conference on "The Global Financial Safety Net and Regional Financial 
Arrangements" held in Seoul in June 2015, especially my discussant Christophe Destais. This article is a substantially revised version of a paper that was previously circulated under the title "The Need and Scope for Strengthening Co-operation Between Regional Financing Arrangements and the IMF".

** Address for correspondence: Department of Economics, SOAS, University of London. Russell Square, London WC1H oXG, UK. Email: uv1@soas.ac.uk 
As the global economy became more interconnected and integrated, the size and volatility of capital flows increased significantly. The increased volatility was a source of instability during the financial crisis. It even adversely affected countries with solid fundamentals and the effects were greater on those with more open economies. These problems persist. Current volatility of capital flows is reflecting the differing speed of recovery between advanced and emerging market economies. National, regional and multilateral responses are required. Strengthened global financial safety nets can help countries to cope with financial volatility, reducing the economic disruption from sudden swings in capital flows and the perceived need for excessive reserve accumulation.

G20 Leaders, The Seoul Summit Document, November 11 - 12, 2010

\section{Introduction}

Under the Korean G20 Presidency in 2010, the G20 Leaders declared the goal of developing and strengthening global financial safety nets. A global financial safety net (GFSN) can be described as "the set of arrangements to provide international liquidity to countries facing sharp reversals in capital inflows despite following sound economic and financial policies" (Truman 2013), including the liquidity assistance provided through the International Monetary Fund (IMF) and regional financing arrangements (RFAs), as well as bilateral or multilateral central bank swap arrangements. While a multitude of arrangements has been in place for a long time, ${ }^{1}$ they have existed largely in parallel, without much coordination between them. Hence, a central challenge for developing a GFSN that deserves its name has been the development a more coherent framework for greater cooperation between the IMF, RFAs, and central banks. At the Seoul Summit in November 2010, the G20 Leaders (2010: §25B) agreed to explore "[w]ays to improve collaboration between RFAs and the IMF across all possible areas and enhance the capability of RFAs for crisis prevention, while recognizing region-specific circumstances and characteristics of each RFA." The goal of strengthening the GFSN and collaboration between the IMF and RFAs has been repeated by the $\mathrm{G}_{2} \mathrm{O}$ in the following years, ${ }^{2}$ and the $\mathrm{G}_{2} \mathrm{O}$ actually managed to agree on common principles for cooperation between the IMF and RFAs which they expected would "strengthen crisis prevention and resolution efforts" (G20 2011a: §14).

Half a decade after the Korean G20 presidency pushed the development of a GFSN, this article reviews the progress made and the challenges remaining for the developing a GFSN that will

\footnotetext{
${ }^{1}$ See Mc Kay et al. (2011) for an overview of the various RFAs.

${ }^{2}$ At the Cannes Summit in November 2011, the G20 Leaders reiterated "to further strengthen global financial safety nets in which national governments, central banks, regional financial arrangements and international financial institutions will each play a role according to and within their respective mandate" (G20 2011a, §14).
} 
contribute to greater stability of the global financial system. It reviews the progress made in developing regional initiatives, the growing importance of bilateral central bank swap arrangements, and the cooperation between different layers of the GFSN. It argues that the GFSN is still very patchy to date and that risks are that it will become even more fragmented with the further development of the European Stability Mechanism, which is expected to de-link from the IMF, and the emergence of the BRICS Contingent Reserve Arrangement. IMF governance reform has stalled, and only little progress has been made in enhancing collaboration between RFAs and the IMF. Hence, future crisis management will have to continue to rely, by and large, on ad hoc policy coordination.

The next section discusses how an 'optimal' GFSN may look like, comprising the IMF, RFAs, as well as bilateral or multilateral central bank swap arrangements, and the relationship between these different layers. Section 3 then briefly reviews and appraises the current structure and functioning of these different layers of the GFSN and the shortcomings of the current structure. Section 4 then discusses the need and scope for further strengthening cooperation between RFAs and the IMF. Section 5 concludes.

\section{How would a global financial safety net look like in an ideal world?}

If a GFSN could be designed from scratch, most would agree that it should involve a strong global organization that that will have sufficient financial resources for providing liquidity finance even during large, systemic global financial crises and the staff capacities for conducting financial and macroeconomic surveillance in member countries and of the world economy at large. Indeed, Keynes' and White's respective proposals at the Bretton Woods conference for an International Clearing Union and a United Nations Stabilization Fund both envisaged such a strong global organization and led to the creation of the IMF. However, as highlighted by Culpeper (2006), global institutions (like the IMF) usually don't serve smaller and poorer countries particularly well. Culpeper (2006: 48) therefore sees regional institutions as an important complement to global institutions because they provide "an institutional space ... in which the voice and voting power of the smaller and poorer countries is greater, along with a greater sense of regional ownership." Moreover, Culpeper argues that by providing competition to global institutions, regional organizations can act as a corrective and provide healthy competition to global institutions. Likewise, Ocampo (2010: 27) argues that "in a heterogeneous international community, the creation of networks of global, regional and national institutions will provide a better system of governance than arrangements based on a single global organisation. This in turn is based on the well-established principle that regional institutions give a stronger voice and a sense of ownership 
to smaller countries, and are more likely to respond to their demands. This has already been recognised in some areas, such as the system of multilateral development banks."

Accordingly, Ocampo $(2006,2010)$ brings forward the argument for a division of labor in the provision of financing between global and regional organizations and suggests a federal network of the Fund and RFAs. Ocampo (2010:24) maintains that "the best global monetary arrangements for the world is a network of the IMF and regional reserve funds and swap arrangements among central banks, which can also serve as frameworks for a multilayered macroeconomic policy dialogue and eventual policy co-ordination." According to Ocampo (2010: 25), the IMF of the future "should be [at] the apex of a network of regional and subregional reserve funds and swap arrangements" In particular, he proposes that the IMF should play a central role in macroeconomic policy coordination at the global level, whereas regional arrangements should have a superior role on a regional and sub-regional level. Ocampo suggests that RFAs could provide full crisis support to small and medium countries, while the IMF should manage the largest balance of payment crises to avoid regional and global contagion effects. Similarly, Gros (2010: 41) envisages a GFSN "built like a pyramid with the ... IMF ... at its apex", where "[r]egional systems would take care of their own members who could pool their resources and IMF membership." Countries that are not part of a regional arrangement would fall under the Fund's responsibility.

Similar to Ocampo and Gros, Henning $(2006,2010,2011)$ proposes a federal structure with a clear division of labor between the IMF and RFAs, but he foresees a more central role for the Fund. Henning (2006: 177-178) suggests a set of principles that RFAs should adopt in order to guide their relationship with the IMF. According to Henning's principles RFAs should (i) create no substantial conflict with members' obligations under the Articles of Agreement; (ii) be at least as transparent as the financial and monetary rules and operations of the IMF; (iii) adopt and pursue sound rules of emergency finance, to be understood as lending into liquidity shortfalls (as distinguished from insolvency) at premium interest rates and with assurance of repayment; and (iv) lend on sound conditionality, understood to mean policy adjustments that eliminate the financing gap in the medium term, or link lending to IMF conditionality directly. Furthermore, Henning recommends that IMF member countries engaged in regional facilities agree (i) to report and disclose the details of their regional cooperative arrangements to the IMF; (ii) to submit their arrangements to the purview and assessment of the IMF's Executive Board; (iii) that regional financial facilities shall not undercut IMF conditionality; and (iv) that regional policies with respect to financial regulation and private-sector involvement must be consistent with stabilization efforts on the part of the IMF. 
Truman (2013), who maintains that the IMF and RFAs are not big enough for today's global shocks, points to central bank swap lines as an important complement. He proposes an institutionalized global swap network, participation in which would be predetermined by central banks based on a number of criteria such as central bank independence and assessments of the stability of their financial systems. While participating central banks would have the final say on whether they agree on the activation of swaps, Truman proposes that the IMF should act as coordinating agency that would declare the need for central bank liquidity support based on a set of objective criteria. The advantage of institutionalizing central bank swaps in such a way would increase predictability, which "adds to stability and reduces the need for inefficient and distortionary insurance mechanisms such as owned reserves" (Truman 2013). Hence, an institutionalized global swap network could form the third layer of the GFSN, besides the IMF and RFAs.

It is important to highlight that the vision of a GFSN as a federal network of the Fund and RFAs, complemented by central bank swaps, is based on the assumption that the IMF as well as RFAs are well-governed institutions that are trusted and respected by their membership and that they collaborate with each other closely. They should also be sufficiently equipped with financial resources and qualified staff to fulfill their mandates. As will be discussed in the following section, neither do the IMF nor all RFAs meet all these requirements. Furthermore, despite some progress on the collaboration between the IMF and RFAs, the reality looks quite different from the ideal sketched out above.

\section{What does the reality look like?}

With the IMF, several RFAs and various bilateral or multilateral central bank swap arrangements, the different layers of the GFSN are already in place (cf. Table 1, Figure 1). Besides the IMF, several regional arrangements have been in existence for longer, most notably the Arab Monetary Fund (AMF, since 1976), the Latin American Reserve Fund (FLAR, since 1978), the North American Framework Agreement (NAFA, since 1994), and the Chiang Mai Initiative Multilateralization (CMIM, since 2000). Two RFAs, the Eurasian Fund for Stabilization and Development (EFSD) and the European Stability Mechanism (ESM) were established only recently, in the course of the global financial and euro crises, respectively. ${ }^{3}$ Moreover, during the global financial crisis, bilateral liquidity swap arrangements between central banks became an increasingly important tool to

\footnotetext{
${ }^{3}$ The Medium-term Financial Assistance Facility was launched in 1971 for all member countries of the then European Community. In 1999, the facility was restricted to non-euro area member states only, because of the 'no bailout' clause (Article 125 of the Treaty on the Functioning of the European Union). The European Financial Stabilisation Mechanism (EFSM) and the European Financial Stability Facility (EFSF) were created as temporary financing mechanisms for the support for all member states in May and June 2010, respectively.
} 
stabilize financial markets (Destais 2014). Most importantly, between December 2007 and October 2008, the Federal Reserve Board established temporary reciprocal currency arrangements with 14 other central banks (Annex 1). The Fed's liquidity swaps, which expired on February 1, 2010, peaked at USD 580 billion in the week ending December 10, 2008 - accounting for more than 25 percent of the Fed's total assets (Fleming and Klagge 2010). In May 2010, the Fed reactivated the swap arrangements with the ECB, the Bank of England, the Bank of Japan, the Bank of Canada and the Swiss National Bank. In October 2013, the Fed Board took the decision to make these temporary swap lines permanent. The other central bank that has negotiated numerous bilateral swap arrangements is the People's Bank of China. In its quest to internationalize the renminbi, the People's Bank of China has agreed on bilateral currency swaps with no less than 31 other central banks and monetary authorities since 2009 (Annex 2). ${ }^{4}$ There are a number of other central bank swap lines, including between the Eurozone and Denmark and Sweden (both in place since 2007); India and Japan (in place since 2013); Korea and the United Arab Emirates (since 2013) and Korea and Australia (since 2014).

[Table 1 and Figure 1 about here]

Thus, the major elements of a comprehensive GFSN are already existent. However, many problems persist that reduce the efficacy of the system, so that in effect the GFSN is a net with many holes. First of all, even though the IMF over the years has adjusted its lending toolkit and revised many of its orthodox views, including those on financial liberalization and capital account management, it is still suffering from a lack of credibility and trust in many developing and emerging economies. The IMF was widely lauded for a quick and decisive response to the Global Financial Crisis. During the crisis, the Fund extended its lending toolkit by introducing new precautionary facilities (Marino and Volz 2012) and was able to triple its lending capacity to USD 750 billion (IMF 2013C). However, IMF resources are generally considered too small. ${ }^{5}$ Since 1975 , IMF quota resources - traditionally the Fund's major source of funding for financial assistance packages - have fallen relative to various metrics of international economic activity, including global GDP, global net capital inflows, global exports, global official reserve assets, and global external liabilities (Nelson and Weiss 2015; Denbee et al. 2016). In December 2010, the Board of

\footnotetext{
${ }^{4}$ On RMB internationalization see Volz (2014).

${ }^{5}$ For instance, European Central Bank Vice-President Vitor Constancio stated: "It is a recognition that, in general, for the world economy, the IMF needs to have more resources if we think ... what in a future emergency situation could be the needs of the IMF to fulfil its role anywhere in the world" (Reuters 2012).
} 
Governors completed the $14^{\text {th }}$ General Review of Quotas by agreeing on a 100 percent increase in total quotas to SDR 477 - the first major quota increase since 1998 - and a major realignment of quota shares giving a greater say to developing and emerging economies (IMF 2015). But the quota increase and realignment did not come into effect until January 2016 as the reform needed approval by three-fifths of the members having 85 percent of the total voting power, and formal approval by the US, which held 17.68 percent of total quota was pending until December $2015 .^{6}$ With the ratification of the $14^{\text {th }}$ General Review of Quotas delayed by the US Congress by five years, frustration has been growing about stalling IMF governance reform, and, as a consequence, the credibility of the Fund has been undermined.

Moreover, the IMF's impartiality was questioned when the Executive Board bent the Fund's own rule of not lending to counties with an unsustainable debt burden during the euro crisis in order to push through the Greek bailout (Wroughton et al. 2015). What is more, critics of the IMF's lending during the euro crisis have pointed out that it's the Fund's role to lend foreign exchange to countries that cannot finance their current account deficit in foreign currency, not in domestic currency. Yet against overt opposition from many of the non-European shareholders, the Europeans, together with the US, pushed through the Greek bailout, again fuelling the impression that the Fund has different, more favorable standards for advanced countries.?

Last but not least, with the appointment of Christine Lagarde as IMF Managing Director in June 2011, the impression was further nurtured that European countries and the US continue to exert over-proportionate influence over the IMF - even though the leaders of the Group of Twenty declared at the London Summit in April 2009 that from now on "the heads and senior leadership of the international financial institutions should be appointed through an open, transparent, and merit-based selection process" (G20 2009: §20).

It is clear that without a meaningful change in its governance structure the IMF can never assume the central role in the GFSN that Henning $(2006,2010,2011)$ and others foresee. Quite the contrary: if IMF governance reform fails, chances are that the prediction will come true that Guido Mantega, the former Brazilian Minister of Finance, made in a statement to the IMF's International Monetary and Financial Committee in October 2007:

\footnotetext{
${ }^{6}$ Since the reform became effective, the US share of total quota decreased slightly to 17.60 percent.

${ }^{7}$ The frustration of many Asian IMF observers is captured in the criticism raised by Ito (2015): "The IMF portrays itself as an unsparing truth-teller, a bastion of economic rationality that can be relied upon in a crisis for tough love and good sense as well as emergency loans. In the eurozone it has fallen short, allowing itself to be used as political cover by leaders in national capitals who have for too long proved unable to speak plainly. In the end, Europe has gained little from this way of doing business. The IMF has forfeited a great deal of credibility, not least with the Asian countries that have been its best students."
} 
“Developing countries [...] would go their own way [...]. We will seek self insurance by building up high levels of international reserves, and we will participate in regional reservesharing pools and regional monetary institutions. The fragmentation of the multilateral financial system, which is already emerging, will accelerate." (McKay et al. 2011:1)

The recent creation of the ACF and the CRA may indeed be a further step in this direction. Against the backdrop of the five-year delay in implementing even the modest quota adjustments agreed in the $14^{\text {th }}$ General Review of Quotas, and widespread dissatisfaction with the Fund's role in Europe, it is not surprising that the progress made in fostering cooperation between the Fund and RFAs has been limited to date. Since the topic was pushed by the Korean G2o presidency in 2010, progress has been largely symbolic. Acknowledging the role of RFAs, the IMF hosted for the first time a high-level meeting at the 2010 Annual Meetings in October 2010 to which it invited representatives of various regional schemes, including the European Financial Stability Facility, the AMF, the FLAR, and various East Asian governments involved in the CMIM (Volz and Caliari 2010: 2). On October 15, 2011, in preparation for the Cannes Summit, the G20 Finance Ministers and Central Bank Governors (2011) agreed on six "Principles for Cooperation between the IMF and Regional Financing Arrangements" (Box 1), that were endorsed by the G20 leaders in Cannes the following month. ${ }^{8}$ Agreement on these principles among the G2O leaders is a welcome development. But there are two problems with these "non-binding broad principles for cooperation": first, they are non-binding, which means that they may or may not be considered in the future; and second, they are very broad and hardly go beyond a general agreement that cooperation between RFAs and the IMF is welcome.

\footnotetext{
${ }^{8}$ With the Korean G20 Presidency's insistence that a global financial safety net be developed, the G20 leaders acknowledged the "need to do further work to improve our capacity to cope with future crises" and tasked the Finance Ministers and Central Bank Governors at the Seoul Summit in November 2010 "to explore, with input from the IMF: A. A structured approach to cope with shocks of a systemic nature. B. Ways to improve collaboration between RFAs and the IMF across all possible areas and enhance the capability of RFAs for crisis prevention, while recognizing region-specific circumstances and characteristics of each RFA." (G20 2010, § 25)
} 


\section{Box 1: G20 Principles for cooperation between the IMF and RFAs}

Based on contributions by the EU [European Union] and by ASEAN +3 countries members of the G20, the following non-binding broad principles for cooperation have been agreed. Also, collaboration with the IMF should be tailored to each RFA in a flexible manner in order to take account of region-specific circumstances and the characteristics of RFAs.

1) An enhanced cooperation between RFAs and the IMF would be a step forward towards better crisis prevention, more effective crisis resolution and would reduce moral hazard. Cooperation between RFAs and the IMF should foster rigorous and even-handed surveillance and promote the common goals of regional and global financial and monetary stability.

2) Cooperation should respect the roles, independence and decision-making processes of each institution, taking into account regional specificities in a flexible manner.

3) While cooperation between RFAs and the IMF may be triggered by a crisis, ongoing collaboration should be promoted as a way to build regional capacity for crisis prevention.

4) Cooperation should commence as early as possible and include open sharing of information and joint missions where necessary. It is clear that each institution has comparative advantages and would benefit from the expertise of the other. Specifically, RFAs have better understanding of regional circumstances and the IMF has a greater global surveillance capacity.

5) Consistency of lending conditions should be sought to the extent possible, in order to prevent arbitrage and facility shopping, in particular as concerns policy conditions and facility pricing. However, some flexibility would be needed as regards adjustments to conditionality, if necessary, and on the timing of the reviews. In addition, definitive decisions about financial assistance within a joint program should be taken by the respective institutions participating in the program.

6) RFAs must respect the preferred creditor status of the IMF.

Source: G20 Finance Ministers and Central Bank Governors (2011).

A further IMF seminar on "Regional Financial Arrangements: Their Role in the International Financial Architecture and Cooperation with the IMF" was held under Russia's G20 presidency on the sidelines of the 2013 IMF and World Bank Spring Meeting with representatives of four RFAs (ACF, CMIM, ESM and FLAR) and senior officials of the G20 governments and central banks. ${ }^{9}$ But besides the convening of such meetings, it is hard to see any discernible impact the G20's efforts have had thus far. Down on the ground, there has been little progress toward fostering (or even institutionalizing) cooperation between the Fund and RFAs and many issues remain open, as will

\footnotetext{
${ }^{9}$ See IMF (2013a) for a stocktaking of the Fund's Engagement with RFAs.
} 
be discussed in detail in the next section. ${ }^{10}$ Fostering cooperation between the Fund and RFAs will be vital to make the GFSN work, since otherwise unhealthy competition between these institutions can at worst undermine global financial stability (McKay et al. 2011).

The IMF's engagement in Europe, which could have led the way for future modes of cooperation between the IMF and RFAs, is widely regarded as a failure. While the ESM (and previously the temporary European Financial Stability Facility) is currently working closely with the IMF, future participation of the IMF in joint programs seems extremely unlikely, given discontent with the IMF in the current joint programs. After the current IMF programs have finished, the IMF is unlikely have any involvement in European affairs again as the EMS is being developed into a full-fledged regional monetary fund (e.g., Rürup 2015). ${ }^{11}$ As recently pointed out by ESM Managing Director Klaus Regling, the ESM has "disbursed $€ 230$ billion in loans to five countries (since 2010), which is two or three times what the IMF has done globally during that period... [The ESM is] the youngest international financial institution but with the biggest balance sheet and the biggest paid-in capital" (POLITICO 2015). Indeed, the ESM's resources are much larger than those of the Fund at the outset of the global financial crisis. And with the European Central Bank now assuming the role of lender of last resort in the euro area, there are little reasons for involving the IMF in any future programs in the Eurozone.

Lastly, the third layer of central bank swap lines has seen only limited development since the global financial crisis. As discussed, the world's most important central banks have been involved in several permanent or temporary swap arrangements. With 31 agreements, the People's Bank of China has spun a rather wide network of swaps, and it is also part of the CRA. The Fed, which is the supplier of the world's most important currency, however, has been very selective in entering swap arrangement, both during the global financial crisis, when not all requests were approved, as well as afterwards when only "the US has offered to provide dollars only to a privileged few" (Eichengreen 2014), namely the central banks of only five advanced economies. An example of a country that has not enjoyed this privilege is Indonesia, whose request for a currency swap with the Fed had already been declined during the global financial crisis; Indonesia reportedly failed again to secure a swap arrangement with the Fed in the summer of 2015 (Chatterjee and Purnomo 2015).

\footnotetext{
${ }^{10}$ A positive example of cooperation between the Fund and an RFA is the annual seminar series organized by AMRO (the ASEAN+3 Macroeconomic Research Office that monitors and analyzes regional economies to support decision-making of the CMIM) together with the IMF and the OECD.

${ }^{11}$ The IMF's involvement has been a contested issue from the start of the euro crisis. French President Nicolas Sarkozy reportedly insisted: "I will never allow the IMF in Europe" (Wroughton et al. 1015).
} 
While central bank swaps can be agreed upon fairly quickly and without parliamentary approval, the problem with such ad hoc arrangements is that they create uncertainty, as only few countries can be sure that they will be able to secure a swap arrangement with a potent central bank in case of liquidity shortages. This uncertainty is costly, especially for developing countries, as their central banks will see a need for holding sizable amounts of foreign exchange reserves as risk insurance. Yet Truman's aforementioned proposal of an institutionalized global swap network has not been picked up.

Summing up, for the time being, the GFSN can be described as a patchwork, which is not adequately equipped to deal with large, systemic crises. Moreover, the fact that the two most important layers - the Fund and RFAs - still operate largely in parallel may create costly delays in times of crises or even undermine financial stability. The next section will therefore discuss ways of strengthening the GFSN by fostering cooperation between RFAs and the IMF.

\section{The need and scope for strengthening cooperation between RFAs and the IMF}

There are important arguments in favor of strengthening cooperation between RFAs and the IMF (Henning 2011; McKay et al. 2011): (i) cooperation would help to avoid "forum shopping" and institutional arbitrage; (ii) cooperation would prevent weakening the IMF's role as the guardian of global financial stability, a role that RFAs cannot assume because of their limited regional mandates; (iii) cooperation would minimize duplication, while at the same time allowing for healthy institutional competition; (iv) cooperation would ensure that the resources provided at one level are additional, rather than substitutes for resources provided at another level; and (v) cooperation would generate mutual gains from a division of labor and specialization based on the comparative advantages of the respective institutions.

Moreover, cooperation with RFAs should be seen as a chance for the IMF to strengthen its global role and ensure its continued relevance. To overcome its stigmatization, the IMF needs to engage with RFAs. The IMF has changed significantly over the last decade: it has become more transparent, it has made (modest) advances in governance reform, giving a greater say to developing and emerging economies, and it has overhauled its lending facilities and conditionality. ${ }^{12}$ Yet many developing and emerging economies still resent the IMF, and for that reason have become more interested in RFAs. Cooperation with RFAs should be viewed as an opportunity to bridge the divide and increase regional and local ownership of potential IMF

\footnotetext{
${ }^{12}$ See Marino and Volz (2012) for early experience with the IMF's recent precautionary facilities.
} 
programs. Cooperation does not preclude competition; indeed, competition for the best analysis and of the brightest ideas should be welcome.

Of course, when discussing cooperation between the IMF and RFAs, it is important to acknowledge the differences as well as comparative advantages of respective RFAs (McKay et al. 2010, 2011). Most RFAs, for instance, enjoy comparative advantages over the IMF with regard to their access to relevant information and greater knowledge of regional economics and politics. However, McKay et al. also show huge differences among the various RFAs with respect to governance, financial resources and analytical expertise, which means that IMF cooperation with RFAs will have to be designed case by case. The G20 Finance Ministers and Central Bank Governors (2011) recognized this, pointing out that "collaboration with the IMF should be tailored to each RFA in a flexible manner in order to take account of region-specific circumstances and the characteristics of RFAs". Yet the broad principles for cooperation are simply too broad to be meaningful. More nuanced guidelines are needed for organizing inter-institutional relations, the division of labor in crisis lending, the terms of joint financial rescue missions, and for surveillance and analysis.

\section{Organizing inter-institutional relations}

A crucial question for framing cooperation between RFAs and the IMF relates to how interinstitutional relations should be arranged (Henning 2011). This has two dimensions. First, how do RFAs organize their external representation towards the Fund and other multilateral institutions? And second, how does the IMF receive representation from RFAs?

Since eligibility for Fund membership is currently restricted to member states, Henning (2001) asks whether IMF membership should be extended to regional organizations/RFAs much as the EU is a member of the World Trade Organization. RFAs could also grant the IMF observer status.

An alternative that would not require changing the IMF Articles of Agreement, would be to group member states of RFAs in multiple-state constituencies at the IMF. ${ }^{13}$ While most current multiplestate constituencies already group together countries of the same region, this is not always the case. For instance, Switzerland (which does not belong to the EU or any RFA) represents Poland, Serbia, and five Central Asian and Eurasian countries. But even for constituencies that comprise countries of the same region, the membership in an IMF constituency is not identical to membership in RFAs of the region. In Latin America, the eight members of the FLAR - Bolivia,

\footnotetext{
${ }^{13}$ Currently only eight out of the Fund's 188 member countries have seat on the IMF's 24-member Executive Board: the United States, Japan, Germany, France, the UK, China, Saudi Arabia and Russia.
} 
Colombia, Costa Rica, Ecuador, Paraguay, Peru, Uruguay and Venezuela - are distributed in three different constituencies (currently chaired by Argentina, Brazil and Spain). Forming a "FLAR constituency" could be an effective way to represent FLAR in the IMF. In East Asia, there is more overlap between current constituencies and RFA membership: the constituency currently chaired by Malaysia includes all ten ASEAN member countries, as well as Fiji, Nepal and Tonga, who are not members of ASEAN+3 or the CMIM. ${ }^{14}$ ASEAN+3 countries could still try to forge common positions on CMIM-related matters through their respective IMF representations, and present these to the IMF board. ${ }^{15}$

European countries' strong presence on the Executive Board ensures European governments' close interchange with the Fund, which is not replicable with other regions. Yet despite a very high level of institutional integration, Europe does not speak with one voice at the IMF. The EU's 28 member countries are scattered in ten different constituencies (with France, Germany and the UK each having their own seat). The 19 euro area members are scattered in eight constituencies. Ireland is in a constituency with Canada, Belize, Jamaica and various small island states. Spain is grouped with several Latin American countries, and rotates a seat on the Executive Board with Colombia, Mexico and Venezuela. Recurring demands for a single EU or euro area seat in the IMF (e.g., Bini Smaghi 2004) have met with resistance from EU members that have their own Executive Directors on the Board. ${ }^{16} \mathrm{~A}$ single seat for the EU - or at least the euro area - would strengthen Europe's voice on the IMF Board, since it would be the IMF's largest shareholder, and also facilitate IMF governance reform and provide more room for emerging and developing countries to have a seat on the Board. Yet individual governments cannot be persuaded to give up their perceived positions of power. However, this European obstinacy should not deter other regions from trying to better organize their IMF representations.

A further option - and the easiest - for organizing the representation of RFAs would be to allow RFAs to obtain IMF observer status. Although Europe is a special case with 19 countries sharing a single currency, it still could be used as an example. Since the IMF's Executive Board granted the ECB observer status in 2002, the ECB is invited to send a representative to Executive Board meetings about surveillance over the common monetary and exchange rate policies of the euro area; the policies of individual euro area members (under Article IV); the role of the euro in the international monetary system; the World Economic Outlook; reports on international capital

\footnotetext{
${ }^{14}$ China and Japan have their own seats on the IMF's Executive Board, while a Korean official is currently Alternate Director in a constituency of 15 Asia-Pacific countries. Hong Kong, SAR, which joined the CMIM in 2010 , is not a member of the IMF.

${ }^{15}$ It is unthinkable that China or Japan would give up their seats (and Korea its rotating seat) for a common ASEAN+3 seat.

${ }^{16}$ These are currently France, Germany, Italy, the Netherlands, Spain and the UK. Several other EU countries are represented on the Board through Alternate Executive Directors.
} 
markets; and developments in the global economy (IMF 2013b). Moreover, the ECB is "invited to send a representative to meetings of the Executive Board on agenda items recognized by the ECB and the Fund to be of mutual interest for the performance of their respective mandates" (IMF 2013: 786). The ECB representative is also allowed to address the Board about matters the ECB considers important. This could serve as a model for non-European RFAs. Of course, RFAs with observer status at the Fund should report and disclose the details of their institutional arrangements with Fund member countries so as to ensure transparency on both sides. ${ }^{17}$

In line with the G20's flexible approach and taking into account region-specific circumstances, RFA member countries should discuss these options among themselves as well as with the IMF Board and either try to organize joint constituencies or seek observer status for "their" RFA.

\section{The division of labor in crisis lending}

A second point relates to the division of labor between the IMF and RFAs in crisis lending. Which circumstances should bring the Fund and RFAs to act as lenders? Should there be any joint lending, and if so, under what conditions?

The current practices differ from case to case. The ACF, the AMF and the FLAR foresee no explicit role for the Fund. In the case of NAFA, the provision of liquidity is not subject to formal conditionality, but participation by the US Treasury, which establishes the conditions for activation on the US side, requires repayment assurances. In the past the US Treasury required that the IMF managing director provides a letter stating their confidence in the economic policies of the borrower when drawing from the Exchange Stabilization Fund (Henning 2002).

The case of the CMIM is interesting, as disbursement of funds is currently linked to the so-called IMF-link. The IMF link in its original form stipulated that a country can only access $10 \%$ of the funds available from the $\mathrm{CMI} / \mathrm{M}$ without having an IMF program, a share that was later increased to $20 \%$. The IMF link, however, is arguably the reason why countries have never turned to the $\mathrm{CMI} / \mathrm{M}$, even at times of liquidity shortage during the global financial crisis. ${ }^{18}$ With reference to the CMIM, Sussangkarn $(2012,215)$ argues that RFAs should act as providers of short-term liquidity with no conditionality, while the Fund should become active only when it is evident that the underlying

\footnotetext{
${ }^{17}$ See Henning's $(2006,177-178)$ proposal for a set of principles that RFAs should adopt in order to guide their relationships with the Fund (cf. Section 2).

${ }^{18}$ Korea, for instance, which was in need of foreign currency liquidity support in 2008, could have accessed USD 18.5 billion under the CMI, but only USD 3.7 billion without IMF program. Korea hence chose to arrange a swap with the Federal Reserve over USD 30 billion (followed by other swaps with China and Japan). Similarly, Indonesia opted for a stand-by loan over USD 2 billion from the World Bank. This suggests that the current IMF link renders the CMIM ineffective, since the stigma of borrowing from the IMF is too costly for East Asian governments, even almost two decades after the Asian crisis.
} 
problem "is not a short-term temporary liquidity problem, but a more fundamental one with a need for significant macroeconomic adjustment policies". He points out that the CMIM is a shortterm swap facility more akin to a central bank swap than a standard IMF loan, given that the CMIM allows the monetary authority of a member country to swap its local currency for an agreed amount of US dollars from the CMIM reserve pool. According to the rules at the time the CMIM was launched, the maturity of each CMIM drawing was 90 days, with an option to roll over the swap up to seven times (i.e., about two years in all). ${ }^{19}$ According to Sussangkarn (2012: 215), the CMIM should thus be seen as "a crisis prevention facility meant to assist an economy in dealing with short-term temporary shortages of foreign currencies such as when a rapid capital outflow occurs like in the case of South Korea during the subprime crisis." In such cases it would "not make sense to impose conditionality of an IMF loan on the economy" (ibid.), hence Sussangkarn recommends doing away with the IMF link in its present form. In his view, the IMF should get involved once "an economy's requested rollover of the swap exceeds a number of times - may be three or four times" (Sussangkarn 2012: 216) since this would signal fundamental weaknesses that would call for structural adjustment.

This proposal raises two concerns. First, where it is clear from the start that a particular economy does not simply face a temporary shortage of foreign currency liquidity but rather has structural deficiencies, valuable time could be lost in making the necessary structural adjustments, since the country's government might be tempted to delay reforms, and instead introduce temporary liquidity support - which would not help to solve the underlying problems. The challenge is to distinguish problems of liquidity and of solvency, since the transition between these is often blurred and a problem with liquidity can quickly turn into a problem of solvency if not addressed quickly.

The second concern relates to the IMF's role as a "bad cop" that takes over RFA crisis management after about a year of unconditional liquidity support. Were this the yardstick for the division of labor between RFAs and the IMF, it would imply that the IMF would only get involved in the tough cases, where painful structural adjustments are needed. Does the IMF want to be in the position to take the blame, leaving RFAs responsible for the "friendly" bit?

An alternative to Sussangkarn's approach of sequencing RFA and IMF involvement would be exploring the establishment of links between the Fund's precautionary facilities (the Flexible Credit Line, FCL, and the Precautionary and Liquidity Line, PLL) and available contingent financing

\footnotetext{
${ }^{19}$ In May 2012 the ASEAN+3 Finance Ministers and Central Bank Governors $(2012,7$.iii) agreed to "lengthen the maturity and supporting period for the IMF linked portion from 90 days to 1 year and from 2 years to 3 years, respectively; and those for the IMF de-linked portion from 90 days to 6 months and from 1 year to 2 years, respectively".
} 
from the respective RFAs. ${ }^{20}$ In the CMIM case, the adjustment to the current IMF link that is needed to make the CMIM fully operational (as argued above) could take the form of recognizing the FCL/PLL as a sufficient condition for drawing on the CMIM beyond the first 30\% (cf. Henning 2011). This would be a way of maintaining an IMF-CMIM link while allowing CMIM member countries to draw on the CMIM without needing to undergo a standard IMF program. As Henning (2011) points out, this would also facilitate activation of the CMIM and help reduce the Fund's stigma in the region. ${ }^{21}$ The non-linked portion could also be increased from the current $30 \%-$ perhaps to $50 \% .{ }^{22}$ Establishing similar linkages with other RFAs could help improve interaction between RFAs and the Fund while also making the Fund's precautionary arrangements more attractive to member countries.

Following a heated discussion in early 2010 about whether the IMF should be involved in the resolution of the European debt crisis, informal cooperation in parallel disbursements has taken place in Europe between the new European facilities and the IMF. Although lending under the temporary European Financial Stabilisation Mechanism (EFSM) and the European Financial Stability Facility (EFSF) as well as the permanent ESM has not been legally tied to IMF disbursement, there has been an informal agreement between the IMF and European authorities that both will proceed simultaneously. ${ }^{23}$ The disbursement of funds has been approved by the "troika" (an expression that is not being used in Europe any more since the Syriza government came into power in Greece in January 2015), which is made up of officials from the IMF, the European Commission and the ECB. The troika also observes enforcement of program conditionality.

\footnotetext{
${ }^{20}$ In May 2012 the ASEAN+3 Finance Ministers and Central Bank Governors decided to introduce a "CMIM Precautionary Line" (CMIM-PL), a facility modelled upon the IMF's recently developed crisis prevention facilities. While there is no agreement yet on the details of this facility, the ASEAN+3 Finance Ministers and Central Bank Governors explicitly agreed on conditionality for the CMIM-PL.

${ }^{21}$ A decade ago, Henning (2002) proposed that the ASEAN+3 agree that prequalification for the Contingent Credit Line, which the Fund abandoned in 2003 due to a lack of takers, should satisfy the CMI definition of an IMF programme.

${ }^{22}$ There were considerable differences among the ASEAN+3 Finance Ministers and Central Bank Governors at their May 2012 meeting regarding the increase of the IMF de-linked portion in 2012. China and Japan - the two biggest contributors to the CMIM - only reluctantly ceded to the demand of ASEAN countries to increase the de-linked portion from $20 \%$ to $30 \%$ and include a reference to a further increase to $40 \%$ in 2014 that would then be "subject to review should conditions warrant" (ASEAN+3 Finance Ministers and Central Bank Governors 2012, 7.ii). The increase to $40 \%$ has not been agreed on since.

${ }^{23}$ The EFSM, which was launched in May 2010, provides that the European Commission could borrow up to EUR 60 billion in financial markets on behalf of the EU under an implicit EU budget guarantee. All EU members were eligible to apply for EFSM financing. The EFSF was created by the member states of the euro area following decisions taken in May 2010. It is backed by guarantee commitments from euro area member states for a total of EUR 780 billion and had a lending capacity of EUR 440 billion. EFSF financing was available only for euro area members. The EFSF was only temporary and was succeeded by the permanent ESM, which was inaugurated in October 2012.
} 
While EFSM/EFSF/ESM lending has been implicitly linked to IMF program, it remains open whether this practice will also apply to ESM lending in the future. Article 8 of the Treaty establishing the European Stability Mechanism states: "The ESM will cooperate very closely with the International Monetary Fund ("IMF") in providing stability support. The active participation of the IMF will be sought, both at technical and financial level. A euro area Member State requesting financial assistance from the ESM is expected to address, wherever possible, a similar request to the IMF." However, since the IMF's involvement in managing the crisis in Greece is widely held to be a failure (for different reasons, depending on which side one stands), it is doubtful that the IMF, which has taken a junior role in the European crisis, will be asked again to join a Eurozone bailout now that the ESM has been fully established. Since the future arrangement between the ESM and the IMF will set a precedent for other RFAs, the Europeans should carefully think the implications for the GFSN.

The procedure for applying to IMF and RFA financing should also be clarified. EU member states are formally required to consult with the European Commission before asking the IMF, or any other international financial institution, for financial assistance. Unsurprisingly, the European Commission was not happy when Poland sought its FCL arrangement with the Fund in April 2009 without giving them prior notice. (Poland argued that the FCL was not a full IMF program but rather an insurance facility.) Other RFAs lack comparable provisions.

How can a joint financial rescue by the IMF and an RFA be arranged?

Thirdly, it is necessary to discuss the modalities and negotiation of cooperation in lending, which involves a (formal or informal) agreement regarding the respective IMF and RFA shares of contributions and the terms of assistance in relation to maturity, interest rates and possibilities of renewing (Henning 2011). The respective loan size depends on the type of lending discussed above, as well as the "firepower" of the respective institution, that is the amount available for lending. The amounts available under the ESM and an extended CMIM will enable these RFAs to act on par with - or even outsize - the Fund's lending, whereas other RFAs, such as FLAR, have only a fraction of the Fund's resources at their disposal.

Regarding the terms of assistance, the G20 Principles (\$5) appropriately demand that "[c]onsistency of lending conditions should be sought to the extent possible". Henning (2011) points out that lending rates need not be identical, but that forum shopping and institutional arbitrage should be avoided (see also McKay et al. 2012). The same applies to the policy conditionality attached to lending. Governments of crisis countries might be inclined to "conditionality shop" - to borrow from the financing arrangement that attaches the weakest 
conditionality to its loan (or none at all) - which could lead to necessary reforms being deferred and increase the risk of the crisis causing even bigger problems.

A further issue to be discussed ex ante between the Fund and RFAs so as to avoid conflicts during crisis negotiations is the creditors' seniority in cases of joint lending by the Fund and RFAs. The IMF has enjoyed de facto preferential creditor status in accordance with its status as an international financial institution. The EFSF did not claim preferred creditor status, since "[p]rivate investors would be reluctant to provide loans to the country concerned if there were too many preferred creditors" (EFSF 2012, 3). The ESM, in contrast, claims "next-in-line" preferred status (Schadler 2014). ${ }^{24}$ But it is not clear that other RFAs will follow this stance, so this issue should be clarified; ideally, RFAs should endorse the G20's demand that "RFAs must respect the preferred creditor status of the IMF" (\$5).

\section{Cooperation in surveillance and analysis}

A fourth point that needs to be addressed relates to cooperation in financial market surveillance and analysis. While in principle, it is desirable to get independent analysis from the IMF and the RFAs - which ideally would stimulate competition for better analysis - cooperation is needed to ensure the efficient use of resources and dissemination of information.

Several concrete steps could be taken: the IMF could invite RFAs to Article IV surveillance missions and (together with the World Bank) to Financial Sector Assessment Programs, subject to approval by the respective government. The current practice of the IMF, European authorities and EU member states collaborating on surveillance, with European officials involved in Article IV consultations, could serve as a model for other regional frameworks. ${ }^{25}$ One positive example from Asia that could be built on is the invitation that the IMF has extended to AMRO officials to participate in parts of the Article IV missions to Japan in recent years.

Discussions and information exchanges during joint missions would not only increase overall understanding of the economy in question, but also help build trust between staff from the IMF and RFAs, and facilitate institutional cooperation in times of crisis. Regular staff exchanges and joint training programs would further enhance knowledge about how all the institutions function.

\footnotetext{
${ }^{24}$ The ESM's High Level Principles for Risk Management state: "Loans to ESM Members will enjoy preferred creditor status in a similar fashion to those of the IMF, whilst accepting preferred creditor status of the IMF over the ESM" (ESM 2015: 1).

${ }^{25}$ It should be noted that while the IMF delegation meets with European officials during its Article IV consultations to EU member countries, European officials are not part of the delegation. I thank Lorenzo Giorgianni for this clarification.
} 
The IMF could also provide capacity-building measures for RFA staff at one of its seven regional training centers - just as it offers training for officials from its member countries.

Enhanced cooperation should not erode the independence of RFAs and reduce them to mere outposts of the IMF, however. The RFA's analytical independence should be maintained, and a competition of ideas should be encouraged in order to avoid the "silo mentality and insular culture" for which the Fund was criticized by its own Independent Evaluation Office (IEO 2011: 1).

However, as discussed before, a major obstacle that stands in the way to increasing cooperation between RFAs and the IMF is the Fund's stalled governance reform. Why should RFA member countries support greater collaboration between 'their' RFA and the IMF when they are not happy with a Fund that is still dominated by large advanced economies? Hence, as important as it will be to push the agenda for cooperation between the Fund and RFAs, the single most urgent item on the reform agenda is IMF governance reform. Without meaningful IMF governance reform, a comprehensive GFSN will remain an illusion. If IMF governance reform fails, the likely outcome will be a fragmentation of the global financial governance system.

\section{Conclusions}

This article has examined the prospects for the development of a comprehensive GFSN. It argues that the GFSN is still very patchy and there is little reason to expect significant progress in better collaboration between RFAs and the IMF as long as the latter's governance structure is not significantly revamped. Indeed, risks are that the GFSN will become even more fragmented with a further development of the ESM, the EFSD and the CRA. To prevent a further fragmentation of the GFSN, the US and the Europeans will need to accept further, more substantial governance reform of the IMF. To make the IMF the globally trusted and accepted institution it ought to be, the US will ultimately have to give up its veto at the Fund and the Europeans will have to accept less seats on the Executive Board. Moreover, it will be important that IMF's credibility is not undermined again by selecting another European Managing Director, no matter how qualified. If developing and emerging economies' trust in the IMF cannot be regained, Guido Mantega's prediction that " $\mathrm{t}] \mathrm{h}$ he fragmentation of the multilateral financial system, which is already emerging, will accelerate" (McKay et al. 2011:1) may hold true. 


\section{Bibliography}

ASEAN+3 Finance Ministers and Central Bank Governors (2012): The joint statement of the 15th ASEAN+3 Finance Ministers and Central Bank Governors' Meeting, Manila, 3 May; online: http://www.mof.go.jp/english/international_policy/convention/asean_plus_3/as3_120503.pdf

Bini Smaghi, L. (2004): A single EU seat in the IMF?, in: Journal of Common Market Studies 42 (2), $229-248$.

BRICS (2014): "Treaty for the Establishment of a BRICS Contingent Reserve Arrangement", Fortaleza, July 15; online: brics6.itamaraty.gov.br/media2/press-releases/220-treaty-for-theestablishment-of-a-brics-contingent-reserve-arrangement-fortaleza-july-15

Chatterjee, N. and H. Purnomo (2015): Indonesia's Request for Fed Dollar Swap Said to Be Rejected, Bloomberg Business, July 10, www.bloomberg.com/news/articles/2015-0710/indonesia-s-request-for-fed-dollar-swap-said-to-be-rejected

Culpeper, R. (2006): “Reforming the Global Financial Architecture: The Potential of Regional Institutions", in: J.A. Ocampo, ed., Regional Financial Cooperation, Brookings Institution Press, Washington DC, 40-67.

Denbee, E., C. Jung and F. Paternò (2016): "Stitching together the Global Financial Safety Net", Financial Stability Paper No. 36, London: Bank of England.

Destais, C. (2014): “Central Bank Currency Swaps and the International Monetary System”, CEPII Policy Brief No. 2014-05, Paris: Centre d'Etudes Prospectives et d'Informations Internationales.

EFSF (European Financial Stability Facility) (2012): Frequently asked questions; online: http://efsf.europa.eu/attachments/faq_en.pdf

Eichengreen, B.J. (2014): The dollar damage done - time to blame the Fed?, The Guardian, February 13, www.theguardian.com/business/economics-blog/2014/feb/13/global-marketdamage-dollar-federal-reserve

ESM (European Stability Mechanism) (2015): “High Level Principles for Risk Management”, 20 May; online: http://www.esm.europa.eu/pdf/ESM\%20High\%20Level\%20Principles\%20for\%20Risk\%20Manage ment\%2oapproved\%20by\%20BoD\%2020-05-2015.pdf

Fed (2008): Minutes of the Federal Open Market Committee October 28-29, 2008; online: http://www.federalreserve.gov/monetarypolicy/fomcminutes20081029.htm

Fender, I. and J. Gyntelberg (2008): Overview: global financial crisis spurs unprecedented policy actions, in: BIS Quarterly Review 13 (4), 1-24. 
Fleming, M.J. and N.J. Klagge (2010): The Federal Reserve's Foreign Exchange Swap Lines, Current Issues in Economics and Finance Vol. 16 (4), New York, NY: Federal Reserve Bank of New York.

G20 (2009): London Summit - Leaders' Statement, 2 April; online: https://www.imf.org/external/np/sec/pr/2009/pdf/g20_040209.pdf

G20 (2010): Leaders' declaration at the G20 Seoul summit; online: http://canadainternational.gc.ca/g2o/summitsommet/2010/g20_seoul_declaration.aspx?lang=eng\&view=d

G20 (2011a): Building our common future : renewed collective action for the benefit of all : Cannes Summit final declaration; online: http://g20-g8.com/g8-g20/g20/english/for-the-press/newsreleases/cannes-summit-final-declaration.1557.html

G20 (2011b): Enhancing the IMF's response capacity and surveillance; online: http://g20g8.com/g8-g2o/root/bankobjects/FMI.pdf

G20 Finance Ministers and Central Bank Governors (2011): G20 principles for cooperation between the IMF and regional financing arrangements; online: http://www.g20-g8.com/g8g20/root/bank_objects/ANG_G20_Principles_for_Cooperation_between_the_IMF_and_Regio nal_Financing_Arrangements.pdf

Henning, C.R. (2002): East Asian financial cooperation, IIE Policy Analyses in International Economics No. 68, Washington, DC: Institute for International Economics.

Henning, C.R. (2006): Regional arrangements and the International Monetary Fund, in E. M. Truman (ed.), Reforming the IMF for the 21st century, PIIE Special Report No. 19, Washington, DC: Peterson Institute for International Economics, 171-184.

Henning, C.R. (2010): Regional financial safety nets and the IMF, in: U. Volz and A. Caliari, eds., Regional and global liquidity arrangements, Bonn: German Development Institute, 36-38. Henning, C.R. (2011): Coordinating regional and multilateral financial institutions, PIIE Working Paper No. 11-9, Washington, DC: Peterson Institute for International Economics.

IEO (Independent Evaluation Office) (2011): IMF performance in the run-up to the financial and economic crisis: IMF surveillance in 2004-07, Evaluation Report, Washington, DC: Independent Evaluation Office of the International Monetary Fund.

IMF (2013a): Stocktaking the Fund's Engagement with RFAs, Strategy, Policy, and Review Department, Washington, DC: International Monetary Fund.

IMF (2013b): Selected decisions and selected documents of the IMF, $37^{\text {th }}$ Issue, December 31, Washington, DC: International Monetary Fund. 
IMF (2013C): Bolstering the IMF’s Lending Capacity, August 05, 2013, Washington, DC:

International Monetary Fund; online:

https://www.imf.org/external/np/exr/faq/contribution.htm

IMF (2015): Factsheet IMF Quotas, April 9; online: www.imf.org/external/np/exr/facts/quotas.htm

Ito, T. (2012): Can Asia overcome the IMF stigma?, in: American Economic Review 102 (3), 198-202.

Ito, T. (2015): Someone needed to speak truth to Europe, Financial Times, July 7.

Marino, R. and U. Volz (2012): A critical review of the IMF's tools for crisis prevention, DIE Discussion Paper No. 4/2012, Bonn: German Development Institute.

McKay, J., U. Volz and R. Wölfinger (2010): Regional financing arrangements and the stability of the international monetary system, DIE Discussion Paper No. 13/2010, Bonn: German Development Institute.

McKay, J., U. Volz and R. Wölfinger (2011): Regional financing arrangements and the stability of the international monetary system, in: Journal of Globalization and Development 2 (1), 19481837

Nelson, R.M. and M.A. Weiss (2015): IMF Reforms: Issues for Congress, CRS Report No. 7-5700, Washington, DC: Congressional Research Service.

Ocampo, J.A. (2006): "Regional Financial Cooperation: Experiences and Challenges”, in: J.A. Ocampo, ed., Regional Financial Cooperation, Brookings Institution Press, Washington DC, 139.

Ocampo, J.A. (2010): The case for and experiences of regional monetary co-operation, in: U. Volz and A. Caliari, eds., Regional and global liquidity arrangements, Bonn: German Development Institute, $24-27$.

Reuters (2012): IMF needs more resources - ECB's Constancio, March 31; online: uk.reuters.com/article/2012/03/31/uk-ecb-imf-idUKBRE82U07C20120331

Rürup, B. (2015) IWF: Danke und Adieu!, Handelsblatt, 28 August

Schadler, S. (2014): “The IMF's Preferred Creditor Status: Does it still Make Sense after the Euro Crisis?", CIGI Policy Brief 37, Waterloo: Centre for International Governance Innovation.

Sussangkarn, C. (2012): Chiang Mai Initiative Multilateralization: origin, development, and outlook, in: Asian Economic Policy Review 6 (2), 203-220.

Truman, E.M. (2013): Enhancing the global financial safety net through central-bank cooperation, VoxEU, September 10; online: www.voxeu.org/article/enhancing-global-financial-safety-netthrough-central-bank-cooperation 
Turner, Z. (2015): Meet Mr. Stability, POLITICO, August 21; online: www.politico.eu/article/esm-imfregling-klaus-regling-lagarde-draghi-greek-crisis-euro-grexit/

Volz, U. (2014): All Politics is Local: The Renminbi's Prospects as a Future Global Currency, in: L. Armijo and S. Katada, eds., The Financial Statecraft of Emerging Powers, Houndmills, Basingstoke: Palgrave Macmillan, 103-137.

Volz, U. and A. Caliari (2010): Introduction, in: U. Volz and A. Caliari, eds., Regional and global liquidity arrangements, Bonn: German Development Institute, 1-7.

Wroughton, L., H. Schneider and D. Kyriakidou (2015): Technocrats in Crisis. How the IMF's misadventure in Greece is changing the fund, Reuters, Aug. 28, 2015; online: www.reuters.com/investigates/special-report/imf-greece/ 
Table 1: Overview of liquidity financing arrangements and major central bank swap arrangements

\begin{tabular}{|c|c|c|c|}
\hline Arrangement & Membership & Established in & Financial resource size \\
\hline \multicolumn{4}{|l|}{ Global } \\
\hline IMF & 188 member countries & 1945 & $\begin{array}{l}\text { Total quotas: USD } 362 \text { billion } \\
\text { (as of } 13 \text { March 2015) } \\
\text { Additional pledged or } \\
\text { committed resources: USD } \\
885 \text { billion }\end{array}$ \\
\hline \multicolumn{4}{|l|}{ Regional financing arrangements } \\
\hline Arab Monetary Fund (AMF) & $\begin{array}{l}22 \text { member countries in the } \\
\text { Middle East and North Africa } \\
\text { (Algeria, Bahrain, Comoros, } \\
\text { Djibouti, Egypt, Iraq, Jordan, } \\
\text { Kuwait, Lebanon, Libya, } \\
\text { Mauritania, Morocco, Oman, } \\
\text { Palestine, Qatar, Saudi Arabia, } \\
\text { Somalia, Sudan, Syria, Tunisia, } \\
\text { Yemen, United Arab Emirates) }\end{array}$ & 1976 & $\begin{array}{l}\text { Authorized capital of USD } 2.6 \\
\text { billion (September 2015). }\end{array}$ \\
\hline $\begin{array}{l}\text { Chiang Mai Initiative Multilateralization } \\
\text { (CMIM) }\end{array}$ & $\begin{array}{l}14 \text { members in East Asia (Brunei, } \\
\text { Cambodia, China, Hong Kong, } \\
\text { Indonesia, Japan, Korea, Laos, } \\
\text { Malaysia, Myanmar, Philippines, } \\
\text { Singapore, Thailand, Vietnam) }\end{array}$ & 2000 & USD 240 billion \\
\hline $\begin{array}{l}\text { Eurasian Fund for Stabilization and } \\
\text { Development (EFSD) (previously called the } \\
\text { Anti-Crisis Fund of the Eurasian Economic } \\
\text { Community, ACF) }\end{array}$ & $\begin{array}{l}6 \text { members in Eurasia (Armenia, } \\
\text { Belarus, Kazakhstan, Kyrgyz } \\
\text { Republic, Russia, Tajikistan) }\end{array}$ & 2009 & $\begin{array}{l}\text { Contributions from member } \\
\text { state budgets: USD } 8.5 \text { billion } \\
\text { (as of June 2015) }\end{array}$ \\
\hline European Stability Mechanism (ESM) & $\begin{array}{l}19 \text { members of the euro area } \\
\text { (Austria, Belgium, Cyprus, Estonia, } \\
\text { Finland, France, Germany, Greece, } \\
\text { Ireland, Italy, Latvia, Lithuania, } \\
\text { Luxembourg, Malta, the } \\
\text { Netherlands, Portugal, Slovakia, } \\
\text { Slovenia, Spain) }\end{array}$ & 2012 & $\begin{array}{l}\text { Subscribed capital: EUR } 704.8 \\
\text { billion } \\
\text { Paid-in capital: EUR } 80.6 \text { (as } \\
\text { of February 3, 2015) }\end{array}$ \\
\hline $\begin{array}{l}\text { Latin American Reserve Fund (Fondo } \\
\text { Latinoamericano de Reservas, FLAR) }\end{array}$ & $\begin{array}{l}8 \text { members in Latin America } \\
\text { (Bolivia, Colombia, Costa Rica, } \\
\text { Ecuador, Paraguay, Peru, } \\
\text { Uruguay, Venezuela) }\end{array}$ & 1978 & $\begin{array}{l}\text { Subscribed capital: USD } 3.6 \\
\text { billion } \\
\text { Paid-in capital: USD } 2.5 \text { billion }\end{array}$ \\
\hline $\begin{array}{l}\text { North American Framework Agreement } \\
\text { (NAFA) }\end{array}$ & Canada, Mexico, US & 1994 & USD 9 billion \\
\hline \multicolumn{4}{|l|}{ Central bank swaps } \\
\hline $\begin{array}{l}\text { BRICS Contingent Reserve Arrangement } \\
\text { (CRA) }\end{array}$ & $\begin{array}{l}\text { Brazil, Russia, India, China and } \\
\text { South Africa }\end{array}$ & 2015 & USD 100 billion \\
\hline $\begin{array}{l}\text { Bilateral currency swap arrangements of the } \\
\text { People's Bank of China with } 31 \text { other central } \\
\text { banks and monetary authorities* }\end{array}$ & $\begin{array}{l}\text { China with } 31 \text { partners (Albania, } \\
\text { Argentina, Armenia, Australia, } \\
\text { Belarus, Brazil, Chile, Eurozone } \\
\text { (ECB), Hong Kong, Hungary, } \\
\text { Iceland, Indonesia, Kazakhstan, } \\
\text { Korea, Malaysia, Mongolia, New } \\
\text { Zealand, Pakistan, Qatar, Russia, } \\
\text { Singapore, South Africa, Sri Lanka, } \\
\text { Suriname, Switzerland, Turkey, } \\
\text { Thailand, United Arab Emirates, } \\
\text { United Kingdom, Ukraine, } \\
\text { Uzbekistan) }\end{array}$ & Since 2009 & $\begin{array}{l}\text { Volumes between RMB } 0.7 \\
\text { billion (with Uzbekistan) and } \\
\text { RMB } 400 \text { billion (with Hong } \\
\text { Kong) }\end{array}$ \\
\hline $\begin{array}{l}\text { Standing swap arrangements between six } \\
\text { major central banks }\end{array}$ & $\begin{array}{l}\text { Fed Reserve Bank, ECB, Bank of } \\
\text { England, Bank of Japan, Bank of } \\
\text { Canada, Swiss National Bank }\end{array}$ & Since $2010 / 2013$ & No limits. \\
\hline
\end{tabular}

Source: Compiled by author with information obtained from the websites of the IMF and various RFAs.

*For details see Annex 2. 
Figure 1: RFAs and bilateral or multilateral central bank swap arrangements

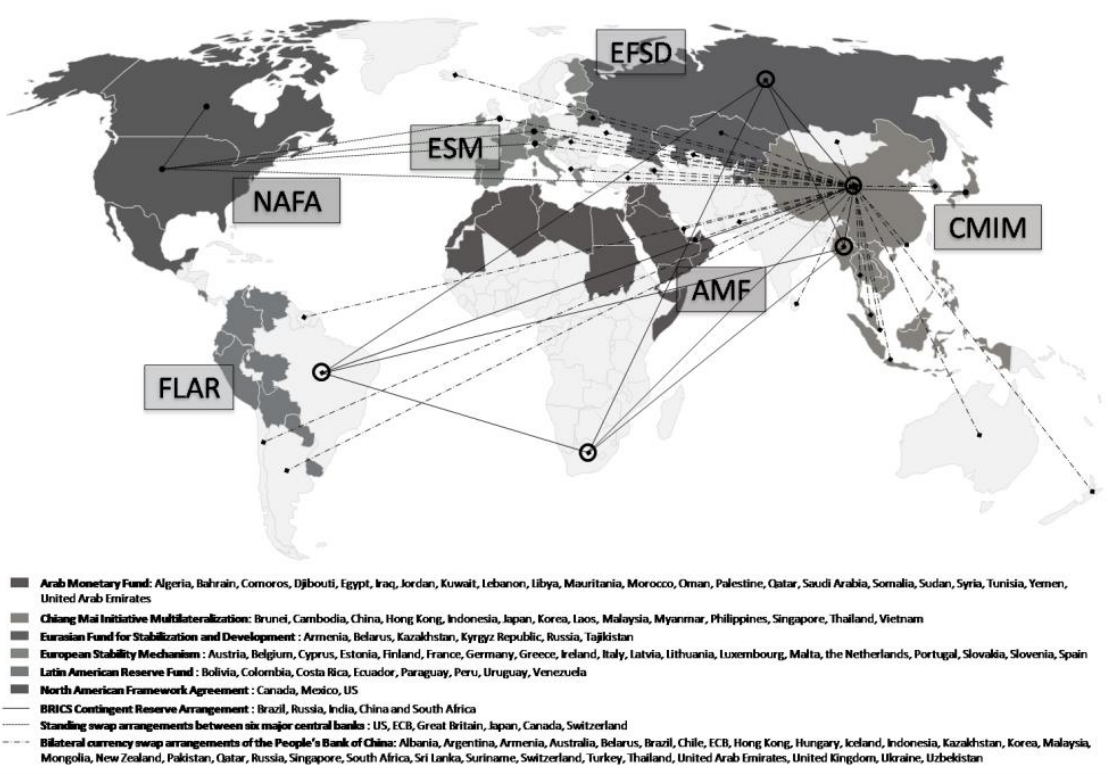

Source: Compiled by author. 
Annex 1: Temporary Fed swap lines opened with central banks during the global financial crisis

\begin{tabular}{|l|l|}
\hline Date & Central bank \\
\hline December 12, 2007 & European Central Bank, Swiss National Bank \\
\hline September 18, 2008 & Bank of Japan, Bank of England, Bank of Canada \\
\hline September 24, 2008 & Reserve Bank of Australia, Sveriges Riksbank, Norges Bank, Danmarks Nationalbank \\
\hline October 28, 2008 & Reserve Bank of New Zealand \\
\hline October 29, 2008 & Banco Central do Brasil, Banco de México, Bank of Korea, Monetary Authority of Singapore \\
\hline
\end{tabular}

Source: Fleming and Klagge (2010:3). 
Annex 2: People's Bank of China's bilateral swap agreements with other central banks (as of September 2015)

\begin{tabular}{|c|c|c|c|}
\hline Country/area & $\begin{array}{c}\text { Amount (in billion } \\
\text { RMB) }\end{array}$ & Date of agreement & Expiration date \\
\hline Albania & 2 & September 2013 & September 2016 \\
\hline Argentina & $\begin{array}{l}70 \\
70\end{array}$ & $\begin{array}{l}\text { March } 2009 \\
\text { July } 2014\end{array}$ & $\begin{array}{c}\text { March } 2012 \\
\text { July } 2017\end{array}$ \\
\hline Armenia & 1 & March 2015 & March 2018 \\
\hline Australia & $\begin{array}{l}200 \\
200\end{array}$ & $\begin{array}{l}\text { March } 2012 \\
\text { April } 2015\end{array}$ & $\begin{array}{c}\text { March } 2015 \\
\text { April } 2018\end{array}$ \\
\hline Belarus & $\begin{array}{c}20 \\
7\end{array}$ & $\begin{array}{c}\text { March } 2009 \\
\text { May } 2015\end{array}$ & $\begin{array}{c}\text { March } 2012 \\
\text { May } 2018 \\
\end{array}$ \\
\hline Brazil & 190 & March 2013 & March 2016 \\
\hline Chile & 22 & Mai 2018 & May 2018 \\
\hline Eurozone (ECB) & 350 & October 2013 & October 2016 \\
\hline Hong Kong & $\begin{array}{l}200 \\
400\end{array}$ & $\begin{array}{l}\text { January } 2009 \\
\text { November } 2011\end{array}$ & $\begin{array}{c}\text { January } 2012 \\
\text { November } 2014\end{array}$ \\
\hline Hungary & 10 & September 2013 & September 2016 \\
\hline Iceland & $\begin{array}{l}3.5 \\
3.5\end{array}$ & $\begin{array}{c}\text { June } 2010 \\
\text { September } 2013\end{array}$ & $\begin{array}{c}\text { June } 2013 \\
\text { September } 2016\end{array}$ \\
\hline Indonesia & $\begin{array}{l}100 \\
100\end{array}$ & $\begin{array}{l}\text { March } 2009 \\
\text { October } 2013\end{array}$ & $\begin{array}{c}\text { March } 2012 \\
\text { October } 2016\end{array}$ \\
\hline Kazakhstan & $\begin{array}{l}7 \\
7 \\
\end{array}$ & $\begin{array}{c}\text { June } 2011 \\
\text { December } 2014\end{array}$ & $\begin{array}{c}\text { June } 2014 \\
\text { December } 2017\end{array}$ \\
\hline Korea & $\begin{array}{l}180 \\
360 \\
360 \\
\end{array}$ & $\begin{array}{c}\text { December } 2008 \\
\text { October } 2011 \\
\text { June } 2013 \\
\end{array}$ & $\begin{array}{c}\text { December } 2011 \\
\text { October } 2014 \\
\text { October } 2017 \\
\end{array}$ \\
\hline Malaysia & $\begin{array}{c}80 \\
180 \\
180 \\
\end{array}$ & $\begin{array}{c}\text { February } 2009 \\
\text { February } 2012 \\
\text { April } 2015 \\
\end{array}$ & $\begin{array}{c}\text { February } 2012 \\
\text { February } 2015 \\
\text { April } 2018 \\
\end{array}$ \\
\hline Mongolia & $\begin{array}{c}5 \\
10 \\
15 \\
\end{array}$ & $\begin{array}{c}\text { May } 2011 \\
\text { March } 2012 \\
\text { August } 2014 \\
\end{array}$ & $\begin{array}{c}\text { May } 2014 \\
\text { May } 2014 \\
\text { August } 2017 \\
\end{array}$ \\
\hline New Zealand & $\begin{array}{l}25 \\
25\end{array}$ & $\begin{array}{l}\text { April } 2011 \\
\text { April } 2014 \\
\end{array}$ & $\begin{array}{l}\text { April } 2014 \\
\text { April } 2017 \\
\end{array}$ \\
\hline Pakistan & $\begin{array}{l}10 \\
10 \\
\end{array}$ & $\begin{array}{l}\text { December } 2011 \\
\text { December } 2014\end{array}$ & $\begin{array}{l}\text { December } 2014 \\
\text { December } 2017\end{array}$ \\
\hline Qatar & 35 & November 2014 & November 2017 \\
\hline Russia & 150 & October 2013 & October 2016 \\
\hline Singapore & $\begin{array}{l}150 \\
300\end{array}$ & $\begin{array}{c}\text { July } 2010 \\
\text { March } 2013 \\
\end{array}$ & $\begin{array}{c}\text { July } 2013 \\
\text { March } 2016 \\
\end{array}$ \\
\hline South Africa & 30 & April 2015 & April 2018 \\
\hline Sri Lanka & 10 & September 2014 & September 2017 \\
\hline Suriname & 1 & March 2015 & March 2018 \\
\hline Switzerland & 150 & July 2014 & July 2017 \\
\hline Turkey & 10 & February 2012 & February 2015 \\
\hline Thailand & $\begin{array}{l}70 \\
70\end{array}$ & $\begin{array}{l}\text { December } 2011 \\
\text { December } 2014\end{array}$ & $\begin{array}{l}\text { December } 2014 \\
\text { December } 2017\end{array}$ \\
\hline United Arab Emirates & 35 & January 2012 & January 2015 \\
\hline United Kingdom & 200 & June 2013 & June 2016 \\
\hline Ukraine & $\begin{array}{l}15 \\
15 \\
\end{array}$ & $\begin{array}{l}\text { June } 2012 \\
\text { June } 2015 \\
\end{array}$ & $\begin{array}{l}\text { June } 2015 \\
\text { June } 2018 \\
\end{array}$ \\
\hline Uzbekistan & 0.7 & April 2011 & April 2014 \\
\hline
\end{tabular}

Source: Compiled by author with information from media reports. 